\title{
The inventories of the Madre de Deus
}

\section{Tracing Asian material culture in early modern England}

\author{
Elsje van Kessel
}

This article examines the impact made by the taking of the ship Madre de Deus in 1592 on the circulation of Asian material culture in England. As a Portuguese cargo ship on its way from Goa, the Madre de Deus was full with precious and exotic objects - an immense treasure for the English privateers who seized it. An examination of the extensive archival record generated by the ship's capture allows for a reconstruction of the cargo. Probing inventories and other documents for their material and formal qualities as much as for their contents, the article argues that written documents became an instrument with which the English authorities tried to control the incontrollable movements of the booty. The pathways subsequently followed by some of the items recovered are followed, and the question of how they affected England's artistic culture is addressed.

And here by the way it is to be noted, that the taking of this Carak wrought two extraordinary effects in England: first, that it taught others, that Caracks were no such bugs but that they might be taken (as since indeed it hath fallen out in the taking of the Madre de Dios, and fyreing and sinking of others) and secondly in acquainting the English Nation more generally with the particularities of the exceeding riches and wealth of the East Indies . . .

WITH these words, Richard Hakluyt (1553-1616), author of The Principal Navigations, Voyages, Trafiques and Discoveries of the English Nation (1599), marks a conclusive moment in the development of the British maritime empire: the taking, by Francis Drake and 
his crew, of the Portuguese carrack São Filipe in the year 1587. As Hakluyt makes clear, this ship was the first coming from Asia to have fallen victim to English privateering, and its taking had important consequences. First of all, it showed the English that carracks - the large cargo ships commonly used by the Portuguese between Goa and Lisbon - could be confiscated, no matter how impressive their size. Furthermore, it was the first time Southeast Asian goods arrived in England in such concentrations. The cargo of the ship demonstrated the variety of objects originating from this area of the world (that was as yet little known to the English) and the money that could be made with them. Hakluyt's account is overtly nationalistic in tone, uninterested in the ethical implications of privateering and exalting the 'English Nation'. Yet this is no reason to simply discredit it. His point - that the arrival of a single ship filled with goods had opened one country's eyes to another, unfamiliar place - is rich with implications. Travelling in much greater numbers than human beings, material objects at the turn of the seventeenth century had the ability to condense time and space, allowing people who might never have undertaken any faraway journey to encounter new worlds. ${ }^{2}$ Objects contributed to the dramatically increased global connectivity that characterized this period, stirring curiosity and whetting appetites for unlimited financial gain. Hakluyt's lines say all these things, but they also make a further, implicit claim: that if the objects are no longer there, words may take their place, recording the unimaginable variety of things the 'Indies' brought forth - exactly as his account replaces and conjures up the material world of a stolen cargo ship.

The São Filipe was therefore a first, but this article focuses on another case study: the vessel Madre de Deus, to which Hakluyt makes passing reference in the passage quoted above but to which, later in his book, he devotes many pages (Fig. 1). Seized from the Portuguese in 1592, the Madre de Deus is the best documented of Elizabethan privateering successes - although for its failures as much as for its triumphs. At sea, and later in 
Dartmouth harbour, large parts of the cargo were embezzled or stolen, never to be seen again. The story of the Madre de Deus is therefore not only one of English heroism and cunning in the face of the Iberian enemy, but also, ironically, one of thieves robbing thieves, and of royally sanctioned pirates begging the Queen for a bigger share in the booty. ${ }^{3}$

What has the story of the Madre de Deus to offer to the history of collections? An underlying premise of this article is that such early cargo ships can meaningfully be reclassified as floating storehouses and their cargoes as collections. ${ }^{4}$ The present 'global turn' in the study of the early modern period has revealed how objects travelled between continents; how they were de- and re-contextualized in new settings; how they produced an impact far away from their place of conception and production (which, in a globalizing world, need not be the same). ${ }^{5}$ Yet, the spotlight is only rarely on the moment of transport itself. Objects, for understandable reasons, are still mostly studied in periods of stasis, and less so during the transitory phase of their transportation from one place to another. The seizing of a ship like the Madre de Deus, however, offers a precious glimpse into this liminal moment which, I would argue, is precisely a moment when objects underwent a change of value. ${ }^{6}$ Furthermore, seized ships - as distinguished from ships that completed their journeys without incident - are particularly revealing, not in the first place for their anecdotal appeal, but because they tend to be much better documented than their 'uneventful' counterparts. Precisely because they were captured by an enemy, they tended to leave impressive paper trails, recording a collection on the brink of dispersal - much like a post-mortem inventory drawn up before the dispersal of its deceased owner's estate. Studying the cargo of the Madre de Deus as a collection, then, means to interrogate its archival records in ways similar to those by which historians of collections approach inventories of households and other land-

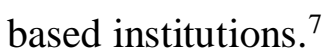


The study of inventories and other lists of things has taken an exciting turn over the past few years, and the present article aims to build on and add to this work. Art history has, of course, long used inventories as sources, yet in their various engagements with early modern inventories, historians of art and material culture have recently begun to examine them as artefacts in their own right. ${ }^{8}$ Moving beyond the inventory as an empirical document, a dry enumeration of facts, these scholars have probed these sources for their hidden agendas, asking about the intentions of their makers, their purposes, and their limitations.

The taking of the Madre de Deus generated a large number of archival documents, particularly in England, including a substantial number of lists of things that belonged or had belonged to the ship's cargo. These will be examined here not as neutral, objective records but as artefacts produced by authors under particular historical, political, economic and cultural circumstances. This means not only looking at the information they convey, but also at the ways in which it is conveyed: issues like language, paratext, lay-out and material are all important. As Giorgio Riello has pointed out, inventories were ubiquitous across the early modern world, yet conventions differed from place to place. ${ }^{9}$ The lists of objects found on the Madre de Deus, then, share characteristics with other inventories and descriptions of things produced in Elizabethan England. Lists in this particular context not only occurred in legal documents but were also pervasive in literary texts. In the words of Janette Dillon, in late Elizabethan and early Jacobean writing a 'sense of the overwhelming material life of objects is regularly produced by the interruption of continuous prose by a catalogue of nouns. ${ }^{10}$ Such lists of material things can have an 'almost fetishized' quality about them, or what Alessandra Russo calls 'textual presence', capable, like Hakluyt's account, of visualizing the listed objects before the mind's eye. ${ }^{11}$ Inventories of the Madre de Deus, studied as artefacts in their own right, can reveal something of the imagined relations between people and things. ${ }^{12}$ 


\section{Seized ships of the Carreira da Índia}

As a Portuguese cargo ship on the India run or Carreira da Índia, the Madre de Deus was one of the four to five vessels that were annually destined to return from Goa to Lisbon filled every inch with goods from the East. By the time the ship was taken, the Portuguese had been building their maritime empire for a century, and during this period Lisbon had become the European hub for African and Asian goods, from which they travelled on to other parts of the continent. The recent work by Annemarie Jordan Gschwend and Kate Lowe has contributed immensely to our understanding of the global nature of Renaissance Lisbon, both in terms of its people and its material culture. ${ }^{13}$ Objects came from wherever the Portuguese had trading posts: for example, sculpted ivories and raffia fibre textiles from the African west coast; carpets from Persia; mother-of-pearl work, filigree, jewellery, silk embroidered wall hangings and bed spreads, ivory sculptures, ebony boxes and cabinets from various parts of coastal India; jewellery, rock crystal objects, and ivory boxes from Ceylon (present-day Sri Lanka); blue and white porcelain from Jingdezhen in China; lacquer tables, cabinets and boxes from Japan. ${ }^{14}$ Alongside this impressive variety of artefacts (and much more importantly in economic terms), the Portuguese imported spices, wood, drugs, gold, silk thread and other raw materials. Some of the objects remained in Portugal, sold on the Rua Nova shopping street or Rossio market and incorporated into aristocratic collections as well as more modest households. ${ }^{15}$ For many other objects and goods, Lisbon was only a temporary stop-over on their way to further European destinations - that is, if the ships managed to return safely to Lisbon at all. As Gschwend points out, the India run was the most dangerous journey in the then known world, and the loss of ships, in the first place due to shipwreck, was common. Unsuccessful as it may have been, the Madre de Deus was not unrepresentative, and can thus shed further light on the European-Asian trade at the end of the sixteenth century from the microperspective of the individual ship. 
While seized ships have been able to count on the sustained interest of historians, in art history little interest as yet exists. ${ }^{16}$ This is to some extent surprising, given that privateering raises fascinating legal and moral questions around booty that art historians have engaged with in relation to land-based warfare of other epochs and geographies. ${ }^{17}$ The decades around 1600 saw an intensification of European maritime expansion into Asia, and with it a dramatic increase in privateering. ${ }^{18}$ From the 1580 s onwards, England (as well as the United Provinces of the Netherlands) increasingly contested Portugal's monopoly in Asia by attacking and seizing Portuguese and Asian ships. This needs to be seen against the background of continuing warfare. In 1581, after a short period of armed conflict, King Philip II of Spain was crowned also as Philip I of Portugal, and until 1640 the country remained in a dynastic union with Spain. ${ }^{19}$ With relations between England and Spain having deteriorated for decades, the first Anglo-Spanish war broke out in 1585, and because of the Iberian union, Portugal was swept into it. ${ }^{20}$ Capturing Portuguese carracks both in Asian and in European waters, English privateers were the first to bring large quantities of Indian and Chinese objects directly to their own country. Privateering had, indeed, profound material consequences: ships' passengers, or other human cargo such as slaves, were randomly disembarked or confiscated as spoils; goods and objects were seized and taken to England, where the ships themselves were hailed as war trophies. This phase of privateering and the legally questionable circulation of Asian objects which resulted from it, preceded the development of the British trading empire. The case of the Madre de Deus enhances awareness of this fact in art history and related object-centred disciplines. In what follows, the particular historiographical difficulties of reconstructing a ship's cargo will be addressed, after which various partial inventories and other documents relating to the cargo of the Madre de Deus will be examined. Finally, the article will discuss the possible subsequent trajectories 
of objects that had been on the ship, and ask how they may have affected the material world of early modern England.

\section{Elusive cargo}

Although the energy of English privateers was usually directed westwards, towards the part of the globe that the pope, a century earlier, had allocated to Spain, in the summer of 1592 things were to go differently. ${ }^{21}$ At the origin of the taking of the Madre de Deus was a large privateering fleet involving such major figures as Walter Raleigh (1552-1618) and Queen Elizabeth (reigned 1558-1603) herself. The original idea had been to sail to Panama for plunder and to intercept the Spanish silver fleet. ${ }^{22}$ But when news reached Raleigh that King Philip, apparently aware of the English threat, had ordered the West Indian ships to stay put, plans were changed: a group of vessels went up north, spying out the Spanish coast line, while the rest, commanded by John Burroughs, sailed to the Azores. There they were joined by a squadron of ships of the Earl of Cumberland, and together they waited for the arrival of the Portuguese carracks that were due to pass by on their way from Goa to Lisbon. The first of these, by the name of Santa Cruz, managed to escape the English grasp, as its crew set the ship on fire, but the second, the Madre de Deus, was taken, after a day's fighting, on the night of 3 August. The vessel, a nau (or, as the English sources often call it, 'the great Carrack'), must have defied every notion that the English had of ships up to that point: as William Drake, who in the middle of the nineteenth century published an extensive scholarly article about the case, formulates it, 'the Carrack was more like a floating house seven stories high than any existing specimen of naval architecture.' 23

What happened to the carrack subsequently, is a story told many times over: until the middle of the twentieth century the taking of the ship was a popular episode in nationalist historiography of the British empire. ${ }^{24}$ As the Earl of Cumberland's men began to board the 
ship, chaos ensued: despite the bodies of Portuguese casualties filling the decks, it was every man for himself, trying to take whatever could be taken. When Burroughs, as commander of the fleet, went on board the Madre de Deus next day, he could barely establish order. When the ship eventually arrived in Dartmouth harbour, early in September, pilfering continued, so that the queen felt compelled to set up a commission in order to retrieve the embezzled goods - a move that had only limited success. Conflicts also arose over the division of the booty another responsibility of the commission: Elizabeth eventually cashed in the lion's share of the profit, at least $£ 83,000$ out of a total of $£ 141,000$ according to Drake's calculations, leaving other stakeholders, most famously Raleigh, remunerated only rather modestly. ${ }^{25}$

Reconstructing the cargo of a ship like the Madre de Deus is a complex task. The cargoes of ships on the Carreira da Índia tend, by definition, to be elusive. Under Portuguese law, anyone on board was permitted to import certain quantities of small goods, called miudezas, to keep or sell as they saw fit, outwith the crown's monopoly. ${ }^{26}$ There was no requirement to register these miudezas, but other goods were also kept off the books: hustling with cargo was an altogether common practice on Portuguese cargo ships. Jan Huygen van Linschoten (c.1563-1611), the Dutch sailor and merchant who spent years on the Carreira da Índia and subsequently published his experiences in his Itinerario, voyage ofte schipvaert naer Oost ofte Portugaels Indien . . (1596), reveals as much. ${ }^{27}$ His account makes clear that it was common usage for Portuguese merchants in India to bribe stevedores: the more one gave, the better the place of one's cargo on the ship. For one vessel that departed from the port of Cochin at the time Linschoten lived in India, this proved to be fatal: paid off by some merchants, the stevedores illicitly exchanged some of the ship's ballast for cinnamon, and, with the harbour still in sight, it capsized and sank. ${ }^{28}$ On board the Madre de Deus, the situation was not much different. As a number of its sailors, taken to England and interrogated by the commissioners, stated: '[E]very of the said Gentlemen and merchants [on 
board the carrack] had some Jewells, as Rubies, Pearles, and suche like, some more, some lesse. The which they do commonlie putt in their chests uppon the upper Decks of the shippe, that at their coming home they may the better convey them secretlie a land. ${ }^{29}$ That is to say, there were various reasons why cargo would remain off the books, including smuggling and embezzlement; official freight lists would in no way give a complete picture of what had actually been stored on board.

To make matters worse, the freight list of the Madre de Deus was probably lost at an early stage: the same document just quoted states that 'the Purser of this Carrick, which was sett a shore, had a booke of all the Lading of the Carrick, but what is become thereof they knowe not. ${ }^{30}$ Perhaps the same happened as with the freight record of the São Tiago, another Portuguese nau, taken by Dutch privateers a few years later: in order to prevent the enemy sailors from obtaining valuable intelligence, the purser of the vessel tied it to a porcelain shard and threw it into the waves. ${ }^{31}$ In other words, written documents, preserved only fragmentarily, have no one-on-one relation with what was in fact on board, a situation of which not a single individual would have had a clear grasp. Rather, I propose, they were an attempt by various authorities and stakeholders to anchor the multitude of things, to pin down what got - quite literally - out of hand. Taken together, the letters, reports, and inventories documenting the Madre de Deus are themselves a complex material fabric, meant to catch the objects they describe, like a (partially incomplete) fishing net. ${ }^{32}$

\section{Hakluyt and the Leadenhall 'Estymate'}

The first inventory of sorts to be examined here is the most familiar one - Hakluyt's summary of the cargo of the Madre de Deus in his Principal Navigations, the book he first published in 1589 but greatly extended for its second edition, published ten years later. ${ }^{33}$ By 
beginning with this published account and gradually working back to lesser-known materials created months or even weeks from the ship's capture, something of the havoc that characterized this first period may be conveyed - a confusion that the many inventories may be said to have attempted to tame. Presenting the evidence counter-chronologically enables me to foreground the historian's archival labour, peeling away layers of historiography and uncovering the contingency of the archival records.

Hakluyt had access to first-hand sources: he knew Raleigh personally and was close with Robert Cecil (1563-1612), 1st Earl of Salisbury and head of the commission charged with retrieving and dividing the carrack's booty. Although in 1599 the English maritime empire was still in an embryonic state, Hakluyt used a retrospective tone when describing the ship and its significance, and in this sense his account evidently differs from the sources we will encounter later.

And here I cannot but enter into the consideration and acknowledgement of Gods great favor towards our nation, who by putting this purchase into our hands hath manifestly discovered those secret trades \& Indian riches, which hitherto lay strangely hidden, and cunningly concealed from us; whereof there was among some few of us some small and unperfect glimse onely, which now is turned into the broad light of full and perfect knowledge. Whereby it should seeme that the will of God for our good is . . to have us communicate with them in those East Indian treasures, \& by the erection of a lawfull traffike to better our meanes to advance true religion and his holy service. ${ }^{34}$

As we have seen, the Madre de Deus was not the first Portuguese carrack taken by the English. Nor was this the first time 'Indian riches' reached England: through the Iberian maritime expansion, such objects had been brought into Europe for almost a century, and were not unknown to people in England involved in trade and collecting. Nevertheless, Hakluyt suggests here that it was this very ship that encouraged the nation to set up legitimate 
trade with the East Indies, thereby hiding the fact that England lagged significantly behind several of her European rivals. Hakluyt is, therefore, mainly responsible for the central position that the taking of the carrack occupies in the historiography of British East India. Furthermore, he ascribes a key role to 'treasures' or 'riches' - that is, things.

In a long passage he lists the variety of objects that comprised the carrack's cargo, a passage that sits towards the end of four and a half densely printed pages narrating the events leading up to and including the seizing of the carrack (Fig. 2):

To give you a taste (as it were) of the commodities, it shall suffice to deliver you a generall particularity of them, according to the catalogue taken at Leaden hall the 15 of September $1592 .{ }^{35}$ Where upon good view it was found, that the principall wares after the jewels (which were no doubt of great value, though they never came to light) consisted of spices, drugges, silks, calicos, quilts, carpets and colours, \&c. The spices were pepper, cloves, maces, nutmegs, cinamom, greene ginger: the drugs were benjamin, frankincense, galingale, mirabolans, aloes zocotrina, camphire: the silks, damasks, taffatas, sarcenets, altobassos, that is, counterfeit cloth of gold, unwrought China silke, sleaved silke, white twisted silke, curled cypresse. The calicos were book-calicos, calico-launes, broad white calicos, fine starched calicos, course white calicos, browne broad calicos, browne course calicos. There were also canopies, and course diaper-towels, quilts of course sarcenet and of calico, carpets like those of Turky; wherunto are to be added the pearle, muske, civet, and amber-griece. The rest of the wares were many in number, but lesse in value; as elephants teeth, porcellan vessels of China, coco-nuts, hides, eben-wood as blacke as jet, bedsteds of the same, cloth of the rindes of trees very strange for the matter, and artificiall workemanship. All which piles of commodities being by men of approved judgment rated but in reasonable sort amounted to no lesse then 150000 li. sterling, which being divided among the adventurers (whereof her Majesty was the chiefe) was sufficient to yeeld contentment to all parties. ${ }^{36}$

I shall return later to the kinds of objects that Hakluyt enumerates - as he points out, things categorized as jewellery, spices, drugs, textiles, and curiosities of various sorts. For now, we may focus on the function of this list within Hakluyt's larger account, that is, to look at the list as a rhetorical device with aesthetic and material properties. 
Placed almost at the end of the chapter on the Madre de Deus, Hakluyt's list can be read as the real climax of the story, as the opening up, before the eyes of the readers, of the treasure trove. The format of the list itself adds to this effect. It clearly interrupts the narrative flow of the historical account. Instead of verbs come nouns and more nouns. This staccato sequence of words referring to material things, only separated from one another by commas, creates a sense of endlessness (Umberto Eco spoke of the vertiginousness of lists). ${ }^{37}$ The textual presence of the listed objects gives Hakluyt's inventory a certain autonomy, both in relation to the surrounding historical narrative, and in connection with the actual objects to which the words refer. ${ }^{38}$ On the page, the things come alive, dancing in front of the reader's eyes as they impress with their abundance. ${ }^{39}$ Rather than merely alluding to them, Hakluyt's list evokes these objects, instilling in his readers the sensation that they have witnessed a spectacle never before seen. However problematic this may seem in the present context, Hakluyt's words disclose a hitherto unknown part of the world by naming its objects.

This effect is enhanced through the author's description of the vessel itself. In this instance, he uses numbers to convince his readers of its record size: 1,600 tons it carried, he writes before plunging into his inventory. ${ }^{40}$ Returning to the subject when the list has ended, thus enveloping its objects in the same way the ship enclosed its cargo, he relays the ship's measurements: 165 feet from the beakhead to the stern, 46 feet 10 inches the carrack's breadth, 121 feet the height of its main mast, etc. ${ }^{41}$ One cannot but feel awe before such a construction: this floating storehouse for the Portuguese merchandise was at the same time a magnificent trophy in itself. With the ship's measurements, Hakluyt's account comes to an end: a triumph of English seafaring and the starting point of England's immensely successful East Indian trade.

The main source for Hakluyt's list of things coming off the ship was the previously mentioned 'Leaden Hall catalogue', which survives to this day. Curiously misdated by him to 
15 September 1592, it was in reality drawn up three months later, on 15 December, after all the goods that remained from the carrack's cargo had been transported to Leadenhall Market in the City of London. While the dating error may indeed be just that, it seems possible that Hakluyt deliberately chose to change the historical record, thus attempting to erase from memory the chaos of the situation.

The Leadenhall list is in fact the single most comprehensive record of all that the Madre de Deus had contained, although it has some significant omissions. At least two copies of it have been preserved: the most monumental one in the British Library, and another version amongst the Cecil Papers at Hatfield House. ${ }^{42}$ The version in the British Library is written on thick, durable paper and takes up the whole two-page spread of the folio (Fig. 3). The writing is of caligraphic quality, which is particularly evident in the first words of the title of the document ('An Estymate'). The lay-out of the page equally has an aesthetic dimension, so that it is the graphic and visual elements of the inventory, such as the accolades that group certain types of objects together, and the white spaces between them, that organize the materials in the first instance. Each of the groups denotes an overarching category of objects: spices, drugs, pigments and dyes, silks, calicoes, carpets and quilts, and a miscellaneous category at the bottom. For each of the items within a subcategory, the inventory mentions the price per unit and the total value, beginning with pepper, the value of which alone amounted to over $£ 70,000$, and ending with the various curiosities, which together were estimated at just over $£ 146$. We find the total estimated value of the goods at the far right: $£ 141,200$.

Perhaps more revealing than what the catalogue includes is what it fails to mention. As we have seen, Hakluyt refers to jewels, in what is the only allusion to the cargo's theft that he seems to have allowed himself. No mention of any piece of jewellery, nor to precious stones, pearls or the like, is made in the Leadenhall list. Neither does the document go into 
any detail when it comes to the 'divers comodities', the kinds of objects so interesting from a collecting point of view: no naturalia are listed and no porcelain. The reasons for these omissions seem to be twofold: as for the jewels, it seems that, indeed, little was retrieved, and as for the curiosities, these were of relatively modest financial value and, within the context of this list, less relevant. The Leadenhall catalogue, then, seems to have been meant primarily to give a succinct, easy-to-grasp overview of what it was all worth. This document translates the great complexity of the Madre de Deus's cargo into one comprehensive table, and exchanges the highly heterogeneous 'exotic' Asian things for something every English reader would have understood: pounds sterling. In the process, problems with theft and embezzlement were forgotten, the creases were ironed out.

Hakluyt's reading of the document further contributed to this process of simplification: his calling it a 'catalogue' for the first time - the word does not, in fact, appear in the document itself - meant a fundamental reinterpretation. As Francesco Freddolini and Anne Helmreich point out, inventories and catalogues are both types of lists, but they differ in important ways. Inventories tend to be records of things found in physical spaces, whereas catalogues are generally more comprehensive, listing things based on a process of selection, and adding further information about them, such as prices. ${ }^{43}$ Catalogues thereby imply a more active role on the part of the list's maker, who chooses, adjoins (that is, curates) often with a commercial or connoisseurial purpose. ${ }^{44}$ By calling the Leadenhall 'Estymate' a 'catalogue', Hakluyt emphazises this curatorial aspect, moving away from the document as a record of objects found, and instead looking into the future towards the objects' sale.

\section{Of embroideries and coconuts: translating things}

However, as the considerable paper trail left by the Madre de Deus in various English archives demonstrates, arriving at the state of clarity suggested by the Leadenhall document - 
even if it was deceptive - had been anything but easy. On 8 October, Thomas Middleton, one of the commissioners for the carrack, wrote to the Lord Treasurer William Burghley that the goods were too disordered to take any inventory of them yet. ${ }^{45}$ Looting had begun as soon as the first English sailors set foot on the carrack's decks. More problematically, it continued while the ship was escorted to Dartmouth and after it docked in the harbour. When the commissioners initiated a hunt for stolen goods, all across southwest England, plenty of things were found, but it is remarkable that few of these seem to have ended up at Leadenhall. The cargo of the Madre de Deus came to Europe as merchandise, then turned into booty, then into stolen goods, then often into merchandise once more.

Very instructive in this light are a Portuguese and an English inventory of goods taken from the carrack by various officials (Figs 4 and 5). ${ }^{46}$ The original, in Portuguese, was written by Vicente de Fonseca, purser of the Santa Cruz whom the English had captured and coerced into collaborating. Fonseca in turn must have talked with Portuguese crew members of the Madre de Deus, as he refers to details given to him by Portuguese informants. The list mentions a range of objects, most of all items of jewellery and quantities of precious stones that were taken by various English captains: rings, rubies, pearls, diamonds, but also musk, ambergris, mace, callicoes, and silks. One of the highlights was certainly 'One Cheste belonginge to the captaine of Selon and therein an embrodarie for a wastecoate sett with diamondes rubies and pearles esteemed with the cheste to be worth 20000 [cruzados]'. An evocative detail is an item at the bottom of Fonseca's list, where he writes: 'he also took from me a piece of coco from the Maldives Islands and fifty golden paternosters [prayer beads] that are worth fifty cruzados'. ${ }^{47}$ Although the prayer beads and the coconut souvenir were negligible in terms of monetary value, they were confiscated nevertheless. ${ }^{48}$

Furthermore, this set of lists is remarkable for its contrasts in terms of presentation: next to the relatively improvised layout of the original document, there is the highly 
organized schema of the English interpretation - not unlike but more radical still than the Leadenhall document. Fonseca's list, illustrated here, is itself a second version of a more basic draft, to which he has added several subheadings and a note in the margin declaring that he witnessed particular objects of Sir John [Burroughs] in person. ${ }^{49}$ The English interpretation is indeed exactly that: it uses the data provided by Fonseca to construct a complex, visually arresting graphic that can be grasped in a single view. As its title reads:

'The reporte of a memoriall delivered by Vincentio de fonseca containing such Jewells stones pearles muske amber greesse and other thinges as to his knowledge and as he understood by others was taken out of the Carricke. Together with an estimate of the valew thereof and also the parties names that had the same as followeth.' In the first column on the left are the names of English captains who had found or confiscated objects with and from certain people and places listed in the second column. The third column is the most dense with information and describes all the objects. In the fourth, fifth and sixth columns the estimated values of the objects are added up, resulting in a total estimate of 114,150 cruzados, or $£ 28,53710$ s. With its high degree of visual organization, this document is a good example of how an inventory can translate information about objects found in physical spaces with other than linguistic means. It also forms evidence, again, of the authorities' attempts to assert control. Yet what happened with the things this list describes so beautifully, remains unclear.

\section{A new list of the cargo of the Madre de Deus}

On the basis of these and many other inventories, it is possible to compile a list, more complete than any previously published overview, of the types of objects contained by the Madre de Deus beyond what is mentioned in the Leadenhall estimate. The following results from a survey of all available archival records known to me, both in the British Library and 
the Cecil Papers at Hatfield House, from the moment the carrack was taken, to the early months of 1593, when the business of the ship was gradually replaced with other news. ${ }^{50}$

Pearls, seed pearls, diamonds, fragments of diamonds, rubies, an emerald, unspecified stones.

Rings set with stones, golden bracelets, collars of pearls, a gold paternoster, spectacular pieces of jewellery such as an unspecified, allegedly very precious 'great jewel,' ${ }^{51}$ two great crosses, a string of pearls with a gold figure of a pelican, a golden ring in the form of a dragon with a sapphire, a gold chain with a cross set with diamonds. Amber, ambergris, musk, tobacco.

Chinese porcelain dishes, a porcelain basin, porcelain ewers.

Mother-of-pearl shells, spoons, a mother of pearl staff.

Silk embroidered pieces of clothing and similar fabrics meant for clothing, often ornamented with pearls and stones, a cloth of [or densely embroidered with] seed pearl, fine tapestries, canopies and bed hangings. Leather carpets, leather garments described as mandilions.

Cabinets, gilded chests, a table board 'such as I thynk ys not to be had in Ingland' 52 bedsteads inlaid with mother-of-pearl, gilded bedposts, gilded tables, a bed head, a gilded casket with golden handles.

Gilded boxes, ivory boxes, a silver basin, a silver fork, a silver girdle, crystal spoons and forks set with gold and stones, knife hafts, a dagger in a golden sheath, a silver gilded clock, gilded targets [small shields].

'India hides' ${ }^{53}$ a piece of coconut, elephant's tusks, a 'yellowish horn'. ${ }^{54}$

A compass, maps, an astrolabe.

Papers, including letters and a treatise on China.

A tent.

Around 400 African slaves ['Nigros'], ${ }^{55}$ who reportedly were put on land on the Azores islands of Corvo and Flores, although at least one was apparently taken to England: one Thomas Ashmore of Holborn acquired from the carrack, amongst several goods, a 'blackamoore' for his wife. ${ }^{56}$

Loosely based around object categories found in the Leadenhall estimate, this list is inevitably a twenty-first-century compilation. Furthermore, it is a list not of actual objects, but of words for objects in archives: it comprises types of objects mentioned in extant 
archival documents, which, as we have seen, have a complicated relationship with the ship's actual cargo. ${ }^{57}$ What, then, can be learnt from this long enumeration of things?

First of all, it allows us to develop further insights into the trade of the Carreira da Índia. While much is said and written about it, detailed evidence of the cargoes of the Portuguese East Indiamen is remarkably scarce. According to Gschwend, only two cargo lists have survived. ${ }^{58}$ This has partly to do with the destruction of the archives of the India House or Casa da Índia in Lisbon during the 1755 earthquake; another reason for the scant survival of documentation is that, for reasons already outlined, many things went deliberately undocumented. The best documented ships are, ironically, those struck by bad fortune: firstly, vessels that were wrecked and have since been investigated by nautical archaeologists, such as the Bom Jesus that sank off the Namibian coast in 1533, or the Nossa Senhora dos Mártires that sank just before it could enter the mouth of the River Tagus at Lisbon in $1606 ;{ }^{59}$ secondly, ships that were seized and which left extensive archival footprints for this reason. Systematic investigation of the Madre de Deus archive, then, adds another valuable example to the very small collection of well-documented Portuguese vessels.

The picture that arises from the cargo of the Madre de Deus is not necessarily one of great surprise: in its composition and volume, it seems to be a fairly representative case. ${ }^{60}$ The majority of the cargo was made up of spices; textiles, primarily calicoes and silks, were another major component. Next to these two large categories, however, there was a great variety of other objects. What makes the Madre de Deus stand out is not so much its cargo per se but rather the evidence for it. In the case of shipwrecks, material remains may consist of porcelain, ivory, and even of spices such as pepper; most other parts of a typical cargo usually perish or get stolen by divers. ${ }^{61}$ Asian art objects transported to Europe in the early modern period and surviving in museums and private collections today are the most eloquent evidence of the Asian trade, yet the stories of their overseas journeys are in most cases 
unknown. The archive of the Madre de Deus makes this part of the provenance of Portuguese-Asian objects more concrete.

In particular, it makes visible a category of objects that we know was important in the Carreira da Índia but often remains elusive: stones and jewellery. ${ }^{62}$ Ironically, it is precisely because gemstones, rings, pearls, bracelets and similar objects were prone to being stolen and to vanish that in the case of the Madre de Deus they have been recorded relatively frequently. The history of the ship enables us to picture the possible provenance of extant pieces in present-day collections. For an object such as the composite ring set with a star-shaped cluster of rubies, probably from Ceylon, now in the Museu Nacional de Arqueologia in Lisbon (Fig. 6), we can now better imagine the kind of pathway leading to its eventual place in a European museum: just such jewels had been acquired in Ceylon and Goa by crew members of the Madre de Deus and the other four carracks sailing back to Lisbon in 1592, many of them likely as miudezas, and just such jewels had been taken off them by the likes of Burroughs, in order to be offered as gifts or sold to English goldsmiths. ${ }^{63}$

Similarly, for the spectacular bangle of rock crystal, gold, rubies and sapphires on loan to the Victoria and Albert Museum, London (Fig. 7), the history of the Madre de Deus brings the jewel's South Indian or Ceylonese origins and early sea voyage to the foreground. The rock crystal bracelet is decorated with four bands of gold running around its circumference, three of them set with small rubies; four larger ornamental settings are of gold scrollwork, rubies and sapphires. ${ }^{64}$ The bangle, now an extremely rare object, was first documented in England in 1587, referred to as 'Persia work' in an inventory of Elizabeth I's jewellery. In fact, it is consistent with the type of jewellery that the Portuguese imported from southern India and Ceylon. ${ }^{65}$ How the bracelet reached England is still unknown.

The archives of the Madre de Deus themselves are not particularly informative about the precise Asiatic origins of the various objects that made up the cargo. Similar objects to 
the bracelet were hardly ever described in terms of their geographical origins by the English commissioners. The label 'India' was applied rather loosely, as in other sources of the time, implying exotic but geographically imprecise origins. ${ }^{66}$ The terms 'China' and 'Cheyney' tend to refer to porcelain as material. The Madre de Deus archives are, therefore, rather sparse in terms of the information they provide about individual objects: elaborate descriptions that might allow identification of extant pieces are simply not there. Instead, it is the importance of materials and of object groups or categories that stands out.

\section{The cargo dispersed: booty invisible}

What does the archive tell us of the circulation of the cargo after the ship arrived at Dartmouth harbour? It is evident that the cargo of the Madre de Deus was never meant to stay in Lisbon exclusively. In the 1580s and 1590s, the Portuguese India trade was a truly European affair, in the sense that the royal monopoly was leased to two consortia of international businessmen, the Fugger family from Augsburg first among them, who distributed the spices to German and Dutch cities as well as to Venice. ${ }^{67}$ Various types of artefacts would also have made their way to northern Europe and Italy, but only in small numbers. The taking of ships like the São Filipe and Madre de Deus by the English, and later the São Tiago and the Santa Catarina by the Dutch, changed this dynamic. Various documents suggest that European interest in the Madre de Deus was strong - and not only from investors such as the Fuggers. The latter sent a petition (now also in the British Library) to Queen Elizabeth, asking her to return the pepper, cloves, mace, and cinnamon that had been intercepted and diverted to England; ${ }^{68}$ evidently this never happened, as can be

understood from a letter of 1603 from the German emperor's ambassador. ${ }^{69}$ European interest also speaks from inventories within the carrack's archive in languages other than English. Amongst the Cecil Papers are summaries of the cargoes of the five Portuguese carracks that 
left India for Lisbon in January 1592, written in Dutch and in French. ${ }^{70}$ Dating from (or relating to confiscations in) September of that year, it is not clear who wrote these lists, completely identical in their contents but different in language and handwriting, nor how they ended up with Cecil. It seems not unlikely, however, that they were produced to whet the appetites of Dutch and Flemish merchants that had come to London to buy from the carrack's cargo, as reported in a letter to the Lord Mayor. ${ }^{71}$ In France, too, news of the booty was out: as a French source reported to Lord Burghley, possibly with some Schadenfreude, 'the capture of the great ship from India had much inconvenienced the merchants of Portugal and Spain and had bankrupted some of them. ${ }^{72}$ It seems possible, therefore, that at least some of the items carried by the Madre de Deus made their way to continental Europe. Remarkably, however, there is nothing to suggest that any gifts were made to European allies, as happened after the Dutch made their conquests some ten years later. ${ }^{73}$ All in all, then, we can assume that the bulk of the carrack's cargo remained on the British Isles.

What would have happened to those goods? Many of the items were materials in need of further manufacture. This is true for the spices, and also, of course, for the calicoes, the silks in various stages of production, and the large quantities of diamonds, pearls, and rubies. ${ }^{74}$ One way or another these South and Southeast Asian materials found their way into English fashion, furnishings, and accessories. Over the centuries, their extra-European origins became almost completely invisible. It is an open and fascinating question how art history and the history of collections should best deal with such raw and elusive materials. ${ }^{75}$ Gemstones, pearls and gold are examples that demonstrate just how problematic this can be: since the ornaments into which they were incorporated frequently were modified as fashions changed, or were melted down if financial need demanded, the connection of such precious materials with the moment of their entry into England is very often lost. ${ }^{76}$ 
In other cases, awareness of the backstories of these materials may lead to new interpretations of artefacts. Take, for example, the portrait of Prince Charles, the future King Charles I in the Scottish National Portrait Gallery (Fig. 8), painted by court artist Robert Peake the Elder around 1610. The image abounds with objects and materials of Asian origin, although this fact has played little role in the (admittedly limited) scholarship on the painting. ${ }^{77}$ The young prince, depicted full-length, stands in a textile-clad room, looking confidently at the viewer, a hand on his waist. A hat sits next to him on a table, embellished with a bird of paradise and a jewel with stones set in gold and cut in various shapes and sizes. The stones, seemingly lined with silver foil, may have been Indian diamonds. ${ }^{78}$ The bird of paradise, with its vibrant yellow colour - one of the focus points of the picture - originated in New Guinea: this is one of the first representations of the species in a painted portrait. ${ }^{79}$ The large pearl hanging from the prince's ear may well have come from Asian waters. The brilliant fabrics of his clothes, put so conspicuously on display in this painting, if not actually produced overseas, would probably have been made of Chinese raw silk among other materials. The carpet on the floor would have been an Asian import, notwithstanding its European name: with its vivid colours separated by narrow lines of black, and large octagonal shapes framed by a narrow outer band, Peake has depicted a typical 'Holbein' carpet, which would have been produced in Anatolia. ${ }^{80}$ All in all, the artist has represented Charles as a figure who had access to all these objects and materials from very far away - objects that may well have made their way to England on a ship like the Madre de Deus. While some of them (most importantly the bird) would have been considered more evidently 'exotic' than others, they all signify the English court's command of global trade. In other words, one claim this painting makes is that this was a ten-year-old boy who had the world's luxury goods at his fingertips. The point also applies more broadly to clothing and accessories of the Elizabethan and Jacobean periods, and painted portraits depicting such objects: even when 
they are not obviously 'exotic' to western viewers and even when they carry European names, they were often made from materials that came from half way round the globe, materials that came initially also from stolen ships. ${ }^{81}$ These considerations should in future play a more prominent and consistent role in art-historical interpretation.

Other objects - finished artefacts - made their way from the Madre de Deus into identifiable collections. For reasons laid out above, it is nearly impossible to trace any object in a collection of the period back to the carrack with certainty, but it is evident that some of the most significant items were offered to Queen Elizabeth and to those in her circle. In the queen's possession, some objects would have continued to circulate as gifts, as we saw in the case of the rock crystal bangle. Others stayed, so that the traveller Thomas Platter observed them when he visited various royal palaces in 1599 and found many objects of exotic origin. ${ }^{82}$ As documents state, an 'armlet of gold and a fork and spoon of crystal with rubies ${ }^{\text {'83 }}$ (for example, Fig. 9) from the Madre de Deus were reserved for the queen, next to a canopy for a bed that was thought to be from Persia. ${ }^{84}$ A gilt table was kept for Lord Burghley, and the tent for the Lord Admiral, Charles Howard. ${ }^{85}$ Another likely recipient was Cecil, the leading commissioner and Burghley's son. As the work of Susan Bracken has made clear, Cecil was one of the most significant collectors of curiosities of his time, whose possessions would have been on a par with better-known Wunderkammern on the European continent. ${ }^{86}$ He celebrated the new English trade in world goods in Ben Jonson's Entertainment for Britain's Burse (1609), which he patronized and co-developed. ${ }^{87}$

In sum, the booty from the Madre de Deus must have had a significant impact on the English material world. As Elizabeth Goldring argues, art history has traditionally represented the Elizabethan period as a sort of wasteland between more fertile artistic eras, an image which she attempts to change with her work on the Earl of Leicester's collecting and patronage. ${ }^{88}$ The study of imported non-European materials, artefacts and art objects, as 
presented here through a focus on a single cargo ship, can help to foreground the tastes of Elizabethan society and contemporary interest in collecting, by highlighting the importance of Asia in the formation of early modern English artistic culture.

\section{Conclusion}

As this article has intended to make clear, the many partial inventories of the Madre de Deus conveyed meaning in a variety of ways: they did so with linguistics, but also through their visual and material make-up. This body of evidence compels us to rethink the relation between archival documents and the objects they describe: these objects often had, to the privateers that seized them, uncertain origins in Asia, and after their capture were not seldom lost again. The documents offer a snippet view of a state that existed only very briefly. These texts were not mere records, but rather instruments with which the English authorities, in the persons of the commissioners and those who assisted them, attempted to control the hitherto uncontrollable circulation of things.

Like no other vessels on the Portuguese India run, stolen ships like the Madre de Deus have left us with archives that contribute to our knowledge of early modern global maritime trade. These archives reveal the stories of objects on the move and convey something of the lived reality on board the massive vessels and of the uncertainties of the ports. The stories of stolen ships, as microhistories, are a small yet essential part of histories of the global.

The case of the Madre de Deus also serves to illustrate a further point: that many, if not most, of the earlier Asian objects and goods to have reached England in the sixteenth century arrived as booty rather than as merchandise. Right in the colonial centre, Asian objects were not only bought and collected but were also looted, embezzled and stolen. To what extent they were understood and displayed as such at the time is a question that 
deserves further research. The implications of the histories of this particular group of ships for the display of relevant objects in museums today, while going beyond the scope of this article, also merit further reflection. In the case of the Madre de Deus, one European state looted from another. In the same period, various Asian nations were similarly involved in piracy and privateering, both as perpetrators and as victims. The redirection of people and things that resulted from this legally and morally questionable yet altogether common practice has ramifications until this day. Greater knowledge of it may helpfully inform current debates about the decolonization of museums.

\section{Address for correspondence}

Elsje van Kessel, School of Art History, University of St Andrews, 79 North Street, St Andrews KY16 9AL, UK

ejmvk@st-andrews.ac.uk

\section{Acknowledgements}

This article was made possible by the generous financial support of the Leverhulme Trust, and by the hospitality of CHAM - Centre for the Humanities at the Universidade Nova de Lisboa. I warmly thank my colleagues José Marcaida and Laura Moretti, who read an earlier draft of this article, for their many invaluable comments and suggestions.

\section{Captions}

Fig. 1. Model of the Madre de Deus (built 1589), Lisbon, Museu de Marinha. [Museu de Marinha]

Fig. 2. Richard Hakluyt, The Principal Navigations, Voyages, Traffiques and Discoveries of the English Nation . . (1599), p. 198, detail. 
Fig. 3. The 'Leadenhall estimate'. British Library, Lansdowne MS 70/89. [British Library Board Lansdowne 70 f208v]

Fig. 4. Vincente de Fonseca, Inventory of goods from the Madre de Deus. Cecil Papers, Hatfield House. [Reproduced by permission of the Marquess of Salisbury, Hatfield House] Fig. 5. 'The reporte of a memoriall delivered by Vincentio de fonseca ...' Cecil Papers, Hatfield House. [Reproduced by permission of the Marquess of Salisbury, Hatfield House] Fig. 6. Ring, Ceylon, c.1550-1600, gold and rubies, $2.7 \times 2.2 \mathrm{~cm}$. Lisbon, Museu Nacional de Arqueologia. [@ Museu Nacional de Arqueologia. Photograph: Paulo Alexandrino. DireçãoGeral do Património Cultural / Arquivo de Documentação Fotográfica (DGPC/ADF)]

Fig. 7. Bracelet, India, sixteenth century, rock crystal, rubies, and sapphires set in gold, $1.3 \times$ $9.0 \mathrm{~cm}$. London, Victoria and Albert Museum; on loan from the collections at Berkeley Castle. [By permission of Berkeley Castle, Gloucestershire (C) Victoria and Albert Museum, London]

Fig. 8. Robert Peake, Portrait of Prince Charles, the future Charles I, c.1610, oil on canvas, $127.0 \times 85.7 \mathrm{~cm}$. Edinburgh, Scottish National Portrait Gallery. [National Galleries of Scotland. Bequeathed by the 13th Baron Elibank 1973]

Fig. 9. Fork and spoon, Ceylon, second half sixteenth century, rock crystal, rubies, sapphire set in gold, $18.7 \times 2.7 \times 1.3 \mathrm{~cm}$ (fork), $20.4 \times 5.1 \times 2.0 \mathrm{~cm}($ spoon). Vienna, Kunsthistorisches Museum. [KHM-Museumsverband]

\section{Notes and references}

${ }^{1}$ R. Hakluyt, The Principal Navigations, Voyages, Traffiques and Discoveries of the English Nation, Made by Sea Or Overland, to the Remote and Farthest Distant Quarters of the Earth, at Any Time Within the Compasse of These 1600 Yeres, vol. II (London, 1599), p. 123.

${ }^{2}$ My application of the term 'thing' is informed by work on materiality, agency and thing theory, including A. Appadurai (ed.), The Social Life of Things: Commodities in cultural perspective (Cambridge, 1986). See also E. J. Campbell, 'Listening to objects: an ecological approach to the decorative arts', Journal of Art Historiography 11 (2014), pp. 1-23, esp. pp. 2-3; M. Koos, 'Wandering things: agency and embodiment in late sixteenth-century English 
miniature portraits', Art History 37 (2014), pp. 836-59, esp. p. 837. On circulating things, see, amongst many other publications, A. Gerritsen and G. Riello (eds), The Global Lives of Things: The material culture of connections in the early modern world (London, 2015); D. Bleichmar and M. Martin (eds), Objects in Motion in the Early Modern World, special issue of Art History 38 (2015); D. Bleichmar and P. Mancall (eds), Collecting Across Cultures: Material exchanges in the early modern Atlantic world (Philadelphia, 2011). For variety I use the terms 'thing' and 'object' interchangeably.

${ }^{3}$ See, in particular, T. Leinwand, Theatre, Finance, and Society in Early Modern England (Cambridge, 1999), pp. 120-8 and references on pp. 185-8; on the taking of the Madre de Deus see further T. Canepa, Silk, Porcelain and Lacquer: China and Japan and their trade with Western Europe and the New World, 1500-1644 (London, 2016), pp. 57-9; R. Loureiro, 'Chinese commodities on the India route in the late 16th - early 17th centuries', Bulletin of Portuguese-Japanese Studies 20 (2010), pp. 87-8; C. R. Boxer, 'The taking of the Madre de Deus, 1592', Mariner's Mirror 67 (1981), pp. 82-4; D. Lach, Asia in the Making of Europe, vol. II (Chicago, 1970), pp. 34-5; E. W. Bovill, 'The Madre de Dios', Mariner's Mirror 54 (1968), pp. 129-52; K. Andrews, Elizabethan Privateering. English privateering during the Spanish War 1585-1603 (Cambridge, 1964), p. 73; L. Stone, An Elizabethan: Sir Horatio Palavino (Oxford, 1956), pp. 207-30; G. C. Williamson, George, Third Earl of Cumberland: His life and his voyages (Cambridge, 1920), pp. 83-112; C. Lethbridge Kingsford, 'The taking of the Madre de Dios', Naval Miscellany 2 (1912), pp. 85-121; M. Oppenheim, The Naval Tracts of Sir Wiliam Monson (London, 1902-1914), pp. 278-96; E. Edwards, The Life of Sir Walter Ralegh, vol. I: Life (London, 1866), pp. 145-58; W. R. Drake, 'Notes upon the capture of "the great carrack" of 1592', Archaeologia 33 (1849), pp. 209-40.

${ }^{4}$ On 'cargo' as a term, see S. Schaffer, 'Instruments as cargo in the China trade', History of Science 44 (2006), pp. 217-46, at p. 218. 
${ }^{5}$ See P. Mason, Infelicities: Representations of the exotic (Baltimore and London, 1998), pp. $1-15$.

${ }^{6}$ On the different values with which early modern objects were invested, see C. Göttler, B. Ramaker and J. Woodall, 'Trading values in early modern Antwerp: an introduction', in Trading Values in Early Modern Antwerp, ed. C. Göttler, B. Ramaker and J. Woodall (Leiden and Boston, 2014), pp. 9-37.

${ }^{7}$ For current art-historical engagement with early modern ships, see C. Swan, 'Fortunes at sea: mediated goods and Dutch trade, circa 1600', in Sites of Mediation: Connected histories of places, processes, and objects in Europe and beyond, 1450-1650, ed. S. Burghartz, L. Burkart, and C. Göttler (Leiden and Boston, 2016), pp. 373-405; see also, among others, continuing work by Bronwen Wilson and Angela Vanhaelen, and Christy Anderson. ${ }^{8}$ F. Freddolini and A. Helmreich, 'Inventories, catalogues and art historiography: exploring lists against the grain', Journal of Art Historiography 11 (2014), pp. 1-14; G. Riello, 'Things seen and unseen: the material culture of early modern inventories and their representation of domestic interiors', in Early Modern Things: Objects and their histories, 1500-1800, ed. P. Findlen (London, 2013), pp. 125-50; J. Keating and L. Markey, 'Introduction: captured objects: inventories of early modern collections', Journal of the History of Collections 23 (2011), pp. 209-13, and the remainder of Keating and Markey's special issue, including A. Russo, 'Cortés's objects and the idea of New Spain: inventories as spatial narratives', Journal of the History of Collections 23 (2011), pp. 229-52. This work ties in with scholarship on the materiality of early modern text more broadly; see, to name but one example, J. ScottWarren, 'Ligatures of the early modern book', Book 2.07 (2017), pp. 33-44.

${ }^{9}$ Riello, op. cit. (note 8).

${ }^{10}$ J. Dillon, Theatre, Court and City, 1595-1610: Drama and social space in London (Cambridge, 2000), pp. 12-3. 
${ }^{11}$ Dillon, op. cit. (note 10), pp. 12-3; Russo, op. cit. (note 8).

${ }^{12}$ See Keating and Markey, op. cit. (note 8).

${ }^{13}$ A. Jordan Gschwend and K. Lowe (eds.), A cidade global: Lisboa no Renascimento / The Global City : Lisbon in the Renaissance (Lisbon, 2017); A. Jordan Gschwend and K. Lowe (eds), The Global City: On the streets of Renaissance Lisbon (London, 2015).

${ }^{14}$ See Gschwend and Lowe 2017, op. cit. [Global City] (note 13); see also J. Levenson (ed.), Encompassing the Globe: Portugal and the world in the 16th \& 17th Centuries (Washington, DC, 2007).

${ }^{15}$ See J. Hallett and N. Senos (eds), De todas as partes do mundo: O Património do $5 .^{o}$ duque de Bragança, D. Teodósio I (Lisbon, 2017); A. Jordan Gschwend, Catarina da Áustria: A rainha colecionadora (Lisbon, 2017); see further Gschwend and Lowe, op. cit. [Global City] (note 13).

${ }^{16}$ See, for example, A. Murteira, 'A navegação portuguesa na Ásia a na rota do Cabo e o corso neerlandês, 1595-1625', Ph.D., Universidade Nova de Lisboa (2016); R. Bertrand, L'Histoire à parts égales. Récits d'une rencontre, Orient-Occident (Paris, 2011), chapter 7; E. van Veen, 'Decay or defeat? An Inquiry into the Portuguese decline in Asia 1580-1645', Ph.D., Universiteit Leiden (2000); V. Enthoven, 'Zeeland en de opkomst van de Republiek: Handel en strijd in de Scheldedelta, c.1550-1621', Ph.D., Universiteit Leiden (1996); Andrews, op. cit. (note 3); a notable, recent exception is Swan, op. cit. (note 7).

${ }^{17}$ For example, M. Miles, Art as Plunder: The ancient origins of debate about cultural property (Cambridge, 2008). Privateering is connected with piracy: both constitute the violent seizing of ships, people and goods at sea. The main difference between the two practices stems from the perspective of the beholder: privateers are state-sanctioned and are therefore of necessity on the right side of the (national) law. See H. Grotius, Commentary on the Law and Prize of Booty, ed. and introd. M. van Ittersum (Indianapolis, 2006), p. 447. 
${ }^{18}$ P. J. de Sousa Pinto, The Portuguese and the Straits of Melaka, 1575-1619: Power, trade, and diplomacy, trans. R. Roy (Singapore, 2012); Murteira, op. cit. (note 16); Enthoven, op. cit. (note 16).

${ }^{19}$ D. Ramada Curto, A cultura política no tempo dos Filipes (1580-1640) (Lisbon, 2011). ${ }^{20}$ It is typical in this context that many of the English sources on the case of the Madre de Deus refer to the ship by its Spanish name (Madre de Dios) or as being Spanish, and identify the language of Portuguese documents erroneously as Spanish as well. For example, 'Cargo of the Carrack', 'Cecil Papers: September 1592', in Calendar of the Cecil Papers in Hatfield House, vol. 4: 1590-1594, ed. R.A. Roberts (London, 1892), pp. 226-32. British History Online http://www.british-history.ac.uk/cal-cecil-papers/vol4/pp226-232.

${ }^{21}$ See Andrews, op. cit. (note 3).

${ }^{22}$ The following summary of events is primarily based on Leinwand, op. cit. (note 3), pp. 120-2, and Drake, op. cit. (note 3), pp. 211-16.

${ }^{23}$ Drake, op. cit. (note 3), p. 216.

${ }^{24}$ See note 3 .

${ }^{25}$ Leinwand, op. cit. (note 3); Drake, op. cit. (note 3), pp. 237-40.

${ }^{26}$ Jordan and Lowe, op. cit. [Global City] (note 13), pp. 301-2; Canepa, op. cit. (note 3), 137.

${ }^{27}$ J. H. van Linschoten, Itinerario, voyage ofte schipvaert naer Oost ofte Portugaels Indien 1579-1592 (Amsterdam, 1596); most recent edition ed. H. Kern and H. Terpstra (The Hague, 1957); translated into English as John Huighen van Linschoten, His discours of voyages into ye Easte and West Indies (London, 1598). See especially chapter 92, p. 60 of Kern and Terpstra's edition: https://dbnl.org/tekst/lins001itin03_01/lins001itin03_01_0003.php\#3. See also Loureiro, op. cit. (note 3), p. 87.

${ }^{28}$ The crew managed to save themselves, but an unspecified number of enslaved people, locked in chains, drowned. Linschoten, op. cit., (note 27), chapter 92, pp. 29-30. 
${ }^{29}$ British Library (hereafter BL), Lansdowne MS 70/36. See also Drake, op. cit. (note 3), pp. $222-3$.

${ }^{30}$ BL, Lansdowne MS 70/36. See also Oppenheim, op. cit. (note 3), p. 293.

${ }^{31}$ Bertrand, op. cit. (note 16), p. 200.

32 'Text', 'texture' and 'textile' share the same Latin etymology. See also Roland Barthes' analogy between text (texte) and woven fabric (tissu) in Le Plaisir du Texte, 1973 (Paris, 2000 edn), p. 126.

${ }^{33}$ For the full passage on the Madre de Deus, see Hakluyt, op. cit. (note 1), pp. 194-9.

${ }^{34}$ Hakluyt, op. cit. (note 1), p. 198.

${ }^{35}$ For the Leadenhall catalogue see below.

${ }^{36}$ Hakluyt, op. cit. (note 1), pp. 198.

${ }^{37}$ U. Eco, The Infinity of Lists: An illustrated essay, trans. A. McEwan (New York, 2009); the reference is from Russo, op. cit. (note 8).

${ }^{38}$ For 'textual presence' see Russo, op. cit. (note 8).

${ }^{39}$ See also Dillon, op. cit. (note 10), pp. 12-13.

${ }^{40}$ Hakluyt, op. cit. (note 1), p. 198.

${ }^{41}$ Ibid., p. 198-9.

${ }^{42}$ BL, Lansdowne MS 70/89; 'Cecil Papers: December 1592', in Calendar of the Cecil Papers, op. cit. (note 20).

${ }^{43}$ Freddolini and Helmreich, op. cit. (note 8), p. 6.

${ }^{44}$ See Freddolini and Helmreich, op. cit. (note 8), p. 6: the Oxford English Dictionary locates the origin of the word 'catalogue' in the Greek $\kappa \alpha \tau \alpha \lambda \varepsilon$ ' $\gamma \varepsilon \imath v$, meaning 'to choose' or 'pick out'. A catalogue, then, is a special type of list of things that someone has chosen to put together. 45 BL, Lansdowne MS 70/71.

${ }^{46}$ Hatfield House, CP 21/95 and CP 21/98. 
47 ' $[\mathrm{M}] \mathrm{e}$ tomou mais hum padaso de coquo das Ilhas de maldiva e sinqoenta patrenostres douro ... que valeraõ sinquoenta cruzados'.

${ }^{48}$ Fonseca may refer to a Maldives coconut or coco de mer (Lodoicea maldivica).

49 'Isto de dom Joaõ tomo testigo de vista e tive tudo na minha maõ.'

${ }^{50}$ Included in this list are all types of objects mentioned in the archival records named above. I have included every type of object only once, even if it is mentioned several times. I have not included any references to quantities, as the records are too fragmented to give reliable quantitative information.

${ }^{51}$ BL, Lansdowne MS 70/36; see also 'Cecil Papers: October 1592', in Calendar of the Cecil Papers, op. cit. (note 20), 1 October 1592.

52 BL, Lansdowne MS 70/62.

${ }^{53}$ Calendar of the Cecil Papers, op. cit. (note 20), 19 October 1592.

${ }^{54}$ Calendar of the Cecil Papers, op. cit. (note 20), September 1592.

55 BL, Lansdowne MS 70/29.

${ }^{56}$ BL, Lansdowne MS 70/56, and see also Drake, op. cit. (note 3), p. 230: ‘a Gilt Targett, xxv cheyney dishes, and 2 Turkey Carpetts, and he hade a blackamore given his wife by Captain Marchan.' Another (albeit in my view less likely) possibility is that the document refers to an artefact representing an African human being. See D. Bindman and H. L. Gates (eds), The Image of the Black in Western Art, vol. III, From the "Age of Discovery" to the Age of Abolition, part 2, Jean Michel Massing, Europe and the World Beyond (Cambridge, MA, 2011), p. xiv (for the term 'blackamoor' as referring to persons of African descent). ${ }^{57}$ In terms of their organization according to typology and materials of which they were made, the Leadenhall estimate and other partial inventories are not unlike household inventories of the same period: see Riello, op. cit. (note 8), pp. 134-5 and references. 
${ }^{58}$ As it is for what the ships themselves looked like: see F. Vieira de Castro, The Pepper Wreck: A Portuguese Indiaman at the mouth of the Tagus River (College Station, TX, 2005). ${ }^{59}$ See Jordan and Lowe, op. cit. [Global City] (note 13); Castro, op. cit. (note 58). ${ }^{60}$ See among others Jordan and Lowe, op. cit. [Global City] (note 13); P. Borschberg, 'The seizure of the Sta Catarina revisited: the Portuguese empire in Asia, vOC politics and the origins of the Dutch-Johor alliance', Journal of Southeast Asian Studies 33 (2002), pp. 3162.

${ }^{61}$ See M. Trusted, 'Survivors of a shipwreck: ivories from a Manila galleon of 1601', Hispanic Research Journal 14 (2013), pp. 446-62; Castro, op. cit. (note 58); also Nossa Senhora dos Mártires: The last voyage (Lisbon, 1998).

${ }^{62}$ On this topic see H. Crespo, Jewels from the India Run (Lisbon, 2015); L. Penalva et al. (eds), Esplendores do Oriente: Jóias de ouro da antiga Goa / Splendours of the Orient: Gold jewels from Old Goa (Lisbon, 2014).

${ }^{63}$ Jordan and Lowe, op. cit. [Global City] (note 11), cat. no. 236 and p. 342.

${ }^{64}$ See https://collections.vam.ac.uk/item/O78342/bracelet/; A. Jordan Gschwend, 'Armreif', in Elfenbeine aus Ceylon. Luxusgüter für Katharina von Habsburg (1507-1578), ed. A. Jordan Gschwend and J. Beltz (Zurich, 2010), p. 91, cat. 35; D. Starkey and S. Doran, Elizabeth I: The Exhibition at the National Maritime Museum (London, 2003), cat. no. 104. ${ }^{65}$ Jordan Gschwend, op. cit. (note 64); Starkey and Doran, op. cit. (note 64).

${ }^{66}$ J. Keating and L. Markey, "“Indian” objects in Medici and Austrian-Habsburg inventories: a case-study of the sixteenth-century term', Journal of the History of Collections 23 (2011), pp. 283-300.

${ }^{67}$ Van Veen, op. cit. (note 16), chapter 3.

${ }^{68}$ BL, Lansdowne MS 70/85. 
69 'Cecil Papers: February 1603', in Calendar of the Cecil Papers in Hatfield House, vol. 12: 1602-1603, ed. R. A. Roberts (London, 1910), pp. 631-60. British History Online http://www.british-history.ac.uk/cal-cecil-papers/vol12/pp631-660.

${ }^{70}$ CP 203/129 (in Dutch) and CP 21/91 (in French).

${ }^{71}$ Acts of the Privy Council of England, vol. 23: 1592, ed. John Roche Dasent (London, 1901), British History Online http://www.british-history.ac.uk/acts-privy-council/vol23, pp. $246-7$.

${ }^{72}$ National Archives, SP 78/29, fol. 366.

${ }^{73}$ Borschberg, op. cit. (note 60), p. 58.

${ }^{74}$ It is an intriguing question, although beyond the scope of this article, whether the taking of the Madre de Deus made a direct impact on English cooking.

${ }^{75}$ For example, see A. Stielau, 'The weight of plate in early modern inventories and secularization lists', Journal of Art Historiography 11 (2014), pp. 1-30. See also L. Jacobi, 'Reconsidering the world-system: the agency and material geography of gold', in The Globalization of Renaissance Art: A critical review, ed. D. Savoy (Leiden and Boston, 2017), pp. 131-57.

${ }^{76}$ For this reason surviving pieces of Sinhalese and South Indian sixteenth-century jewellery are extremely rare; Gschwend and Lowe, op. cit. [Global City] (note 13), p. 342.

${ }^{77}$ See, however, J. Marcaida, 'Rubens and the bird of paradise: painting natural knowledge in the early seventeenth century', Renaissance Studies 28 (2014), pp. 112-27, especially p. 120. For this painting see further 'Charles I, 1600-1649. Reigned 1625-1649', https://www.nationalgalleries.org/art-and-artists/2098/5121/charles-i-1600-1649-reigned1625-1649; A Companion Guide to the Scottish National Portrait Gallery (Edinburgh, 2008), p. 23; also R. Strong, The English Icon: Elizabethan and Jacobean portraiture (London, 1969), p. 250. On the relation between painting, exotic objects and collecting see also J. 
Marcaida López, Arte y ciencia en el barroco español: Historia natural, colleccionismo y cultura visual (Seville and Madrid, 2014).

${ }^{78}$ See, for example, N. N. Haidar and C. A. Stewart, Treasures from India: Jewels from the Al-Thani Collection (New York, 2014), pp. 62 and 66.

${ }^{79}$ Companion Guide, op. cit. (note 77), p. 23; on birds of paradise in the early modern period, see Marcaida, op. cit. (note 77); Marcaida López, op. cit. (note 77), pp. 220-52; C. Swan, 'Exotica on the move: birds of paradise in early modern Holland', Art History 38 (2015), pp. 620-35.

${ }^{80}$ See J. Harris (ed.), Five Thousand Years of Textiles (London, 1993), p. 120.

${ }^{81}$ See Marcaida, op. cit. (note 77), p. 120 note 33. On exotic objects in European paintings, see also B. E. Hamann, 'The mirrors of "Las Meninas": cochineal, silver, and clay', Art Bulletin 92 (2010), pp. 8-35. See further, L. Molà and M. Ajmar-Wollheim, 'The global Renaissance: cross-cultural objects in the early modern period', in Global Design History, ed. G. Adamson, G. Riello and S. Teasley (London, 2011), pp. 11-20.

${ }^{82}$ T. Platter, Thomas Platter's Travels in England, 1599, trans. and ed. C. Williams (London, 1937); see also Lach, op. cit. (note 3), pp. 34-5.

83 'Queen Elizabeth - Volume 243: September 1592', in Calendar of State Papers Domestic: Elizabeth, 1591-94, ed. Mary Anne Everett Green (London, 1867), pp. 266-77. British History Online http://www.british-history.ac.uk/cal-state-papers/domestic/edw-eliz/15914/pp266-277, 19 September 1592.

${ }^{84}$ BL, Lansdowne MS 70/62. For the illustrated fork and spoon see Jordan and Lowe, op. cit. [Global City] (note 11), p. 342.

${ }^{85}$ The table was conceivably a namban lacquer table; on this type of object see Canepa, op. cit. (note 3), p. 343. 
${ }^{86}$ S. Bracken, 'Robert Cecil as art collector', in Patronage, Culture, and Power: The early Cecils, ed. P. Croft (New Haven and London, 2002), pp. 121-37; see also S. Bracken, ““Chyna” in England before 1614', Oriental Art 47 no. 2 (2001), pp. 8-10.

${ }^{87}$ J. Knowles, “To raise a house of better frame': Jonson's Cecilian entertainments', in Croft, op. cit. (note 86), pp. 181-95.

${ }^{88}$ E. Goldring, Robert Dudley, Earl of Leicester, and the World of Elizabethan Art: Painting and patronage at the court of Elizabeth I (New Haven, 2014). 